$14^{\text {th }}$ Conf. Agric. Develop. Res., Fac. of Agric., Ain Shams Univ., March, 2019, Cairo, Egypt

Special Issue, 27(1), 847 - 851, 2019

Website: http://strategy-plan.asu.edu.eg/AUJASCI/

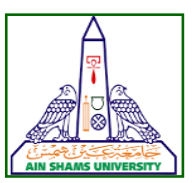

\title{
BIOLOGICAL ASPECTS AND LIFE TABLE PARAMETERS OF THE EGGPLANT STEM BORER, Euzophera osseatella Treit. (Lep.: Pyralidae)
}

\author{
Samar, M. Abbas, Hekal, A.M. and Youssef, L.A. \\ Plant Protection. Dept., Fac. of Agric., Ain Shams Univ., P.O. Box 68, Hadyek Shoubra 11241, \\ Cairo, Egypt
}

*Corresponding author: samarmagdy1726@gmail.com

Received 12 September, 2018, $\quad$ Accepted 9 October, 2018

\begin{abstract}
Biological aspects and life table parameters of the eggplant stem borer, Euzophera osseatella Treit. (Lep.: Pyralidae) were studied under laboratory conditions at $27^{\circ} \mathrm{C}$ and $65 \%$ R.H. The egg, larval and pupal stages of E. osseatella lasted 5.8, 33.2 and 12.9 days, respectively. The mortality percentage in the corresponding stages reached 14,37 and $13 \%$, respectively. The sex ratio in $E$. osseatella was in favour of females (1:1.1). The preoviposition, oviposition and postoviposition periods of the pest averaged 1.8, 3.1 and 1.2 days, respectively. The daily and total numbers of eggs/female of $E$. osseatella were 46.6 and 147.2, respectively. The male and female of the insect lived 4.4 and 6.2 days, respectively.

The mean generation time ( $\mathrm{T}$ ) of $E$. osseatella averaged 54.22 days. The net reproductive rate $\left(R_{0}\right)$, the intrinsic rate of increase $\left(r_{m}\right)$ and the finite rate of increase (exp. $r_{m} / \lambda$ ) in the pest were 28.09, 0.062 and 1.063, respectively. The generation doubling time (Dt) of $E$. osseatella reached 14.01 days. The fecundity curve $\left(M_{x}\right)$ of $E$. osseatella showed three peaks of $14.14,20.14$ and 12.32 female progeny/female/day at the female age $(X)$ of $50.5,61.5$ and 63.5 days, respectively. The survival curve ( $L x)$ of the insect revealed that most death of females occurred after an extended oviposition period to compensate failure of most immature stages to reach maturity (64\%).
\end{abstract}

Key words: Euzophera osseatella, biological aspects, life table parameters

\section{INTRODUCTION}

E. osseatella is an economically important pest infesting some species and varieties of Solanaceae plants in several continents (Cameron, 1963; Rivnay, 1966; Ferial, 1969 and Berlinger, 1986). In Egypt, host plants of this pest include eggplant, potato, pepper, tomato, kangaroo apple and black nightshade (Ferial, 1969; Harakly, 1974; Shaheen, 1979; Moftah, 1985 and Oda, 2012). Eggplant varieties showed highly significant differences in their susceptibility to E. osseatella infestation (Ferial, 1969). The Rumy variety was highly infested, followed by varieties of Baladi Black and Baladi White.

E. osseatella larvae feed on pithy and woody portions in stems and branches of host plants, as well as internal tissues in potato tubers in the field. The larvae cause holes in stems, branches and tubers (Cameron, 1963 and Harakly, 1965). Infested plants are weakened with easily breakable stems and reduced yields. Microorganisms develop in larval tunnels causing rots, which finally kill plants (Rivnay, 1966). E. osseatella infestation on eggplant began two months after transplanting and increased progressively to 70 and $90 \%$ one and three months later, respectively (Ferial, 1969). E. osseatella is found all the year round, but it obviously decreases in winter (Harakly, 1965). The larvae hibernate during winter inside stems of host plants.

Several authors studied biological aspects of $E$. osseatella, but they never dealt with life table parameters (Harakly, 1965; Rivnay, 1966; Hammad, 1968 and Ferial, 1969). Therefore, the pre- 
sent work aimed to estimate life table parameters of this pest reared on potato tubers under laboratory conditions.

\section{MATERIALS AND METHODS}

\section{Rearing of E. osseatella}

Samples of Rumy eggplant stems infested with E. osseatella were collected from Damanhur region in El-Beheira Governorate during 2017. They were placed in wooden cages and left until emergence of moths. The emerged males and females of the pest were put in glass chimneys adjusted on glass dishes and covered with cloth secured with rubber bands. Each glass chimney was offered a cotton piece moistened with $10 \%$ sugar solution for feeding moths, as well as potato tubers and cloth strips to serve as oviposition sites. Potato tubers and cloth strips carrying $E$. osseatella eggs were taken and placed in glass jars covered with cloth secured with rubber bands until the hatching. Newly hatched larvae bore into potato tubers, feed on internal tissues and pupate in silken cocoons until emergence of moths. Infested potato tubers were replaced with newly sound ones, when it was necessary.

\section{Biology of E. osseatella}

To study biological aspects of E. osseatella, 100 fertilized eggs were taken from the culture, divided into 10 replicates of 10 eggs each and put in glass jars provided with potato tubers. E. osseatella eggs laid on cloth strips were better than those deposited on potato tubers, because they were easily separated into comparatively few numbers. They were daily examined under a stereomicroscope to record the hatching rate and incubation period. The neonate larvae enter potato tubers, bore tunnels and pupate outside or inside them depending on the larval feeding extent, which affects the condition of tubers. Fourth and fifth instar larvae of $E$. osseatella often emerged from decomposed potato tubers to pupate outside. Therefore, the former were transferred to new potato tubers to complete their feeding. However, the latter were transferred to new glass jars supplied with small pieces of cloth to facilitate the cocoon spinning until emergence of moths. Larval and pupal mortalities, as well as larval and pupal periods were daily recorded. The pest larvae sometimes remained in coherent potato tubers to pupate inside them leading to a great difficulty to follow up larval and pupal stages. So, potato tubers were periodically opened to determine the insect development and record the previous data.

After the moth emergence, the total number of E. osseatella moths was counted and the sex ratio was estimated. Each pair of moths was studied as it was mentioned above. Preoviposition, oviposition and postoviposition periods, as well as the longevity of males and females were calculated. Daily and total number of eggs laid / female of $E$. osseatella were also recorded.

\section{Life table of E. osseatella}

To estimate life table parameters of $E$. osseatella, the duration of immature stages, mortality rate, sex ratio, total number of deposited eggs / female and number of alive females were utilized. Life table parameters were calculated according to Birch (1948) by using the basic computer program (Abou-Setta et al 1986).

\section{RESULTS AND DESCUSSION}

\section{Biological aspects of E. osseatella}

The egg, larva, pupa and total development of E. osseatella lasted 5.8, 33.2, 12.9 and 51.4 days at $27{ }^{\circ} \mathrm{C}$ and $65 \%$ R.H., respectively (Table 1). The mortality percentage in the egg, larva, pupa and total immature stages of the pest reached 14, 37, 13 and $64 \%$, respectively. The sex ratio in $E$. osseatella was in favour of females (1:1.1).

The preoviposition, oviposition and postoviposition periods of $E$. osseatella averaged 1.8, 3.1 and 1.2 days, respectively (Table 2 ). The daily and total numbers of eggs / female of the pest were 46.6 and 147.2, respectively. The male and female of $E$. osseatella lived 4.4 and 6.2 days, respectively.

\section{Life table parameters of E. osseatella:}

The mean generation time $(\mathrm{T})$ of $E$. osseatella averaged 54.22 days (Table 3 ). The net reproductive rate $\left(R_{0}\right)$ is the net increase rate of the pest population, which equals 28.09 . The intrinsic rate of increase $\left(r_{\mathrm{m}}\right)$ means the real increase rate of $E$. osseatella population and equiponderates 0.062 . The finite rate of increase (exp. $\left.r_{m} / \lambda\right)$ expresses the multiplicative increase rate in a time unit of the insect population and equals 1.063. The generation doubling time (Dt) of $E$. osseatella reached 14.01 days. 
The fecundity curve $\left(\mathrm{M}_{\mathrm{x}}\right)$ of $E$. osseatella showed three peaks of $14.14,20.14$ and 12.32 female progeny / female / day at the female age (X) of 50.5, 61.5 and 63.5 days, respectively (Fig. 1). The survival curve $\left(L_{x}\right)$ of the insect revealed that most death of females occurred after an extended oviposition period to compensate failure of most immature stages to reach maturity (64\%).

Similar biological trends were reported by Harakly (1965) who found that the sex ratio in $E$. osseatella was in favour of females $(55.5 \%)$. The fertilized female laid up to 292 eggs at $27^{\circ} \mathrm{C}$. Rivnay (1966) clarified that the egg, larval and pupal stages of E. osseatella lasted 6.0, 26.9 and 12.6 days, respectively at $27^{\circ} \mathrm{C}$. The preoviposition and oviposition periods of the pest took 3.2 and 1-6 days, respectively at $26^{\circ} \mathrm{C}$. The female laid $1-300$ eggs. Ferial (1969) stated that the mated female of E. osseatella laid 158.3 eggs at $26.3^{\circ} \mathrm{C}$.

Table 1. Duration and mortality of $E$. osseatella immature stages reared on potato tubers and sex ratio of emerged moths at $27 \pm 2^{\circ} \mathrm{C}$ and $65 \pm 5 \%$ R.H.

\begin{tabular}{|c|c|c|c|c|c|c|c|c|c|c|c|}
\hline \multicolumn{2}{|c|}{ Egg stage } & \multicolumn{2}{|c|}{ Larval stage } & \multicolumn{2}{|c|}{ Pupal stage } & \multicolumn{2}{|c|}{ Immature stages } & \multicolumn{3}{|c|}{ N. of emerged moths } & \multirow[b]{2}{*}{$\begin{array}{c}\text { Sex } \\
\text { ratio } \\
0:+\end{array}$} \\
\hline $\begin{array}{c}\text { Incubation } \\
\text { period } \\
\text { (days) }\end{array}$ & $\begin{array}{c}\% \\
\text { Mortality }\end{array}$ & $\begin{array}{l}\text { Larval } \\
\text { period } \\
\text { (days) }\end{array}$ & $\begin{array}{c}\% \\
\text { Mortality }\end{array}$ & $\begin{array}{l}\text { Pupal } \\
\text { period } \\
\text { (days) }\end{array}$ & $\begin{array}{c}\% \\
\text { Mortality }\end{array}$ & $\begin{array}{l}\text { Total } \\
\text { period } \\
\text { (days) }\end{array}$ & $\begin{array}{c}\% \\
\text { Mortality }\end{array}$ & Total & Male & $\mathrm{Fe}$ & \\
\hline $\begin{array}{c}5.8 \pm 0.6 \\
(5-6)\end{array}$ & 14 & $\begin{array}{c}33.2 \pm 2.0 \\
(25-40)\end{array}$ & 37 & $\begin{array}{c}12.9 \pm 1.9 \\
(5-19) \\
\end{array}$ & 13 & $\begin{array}{c}51.4 \pm 0.9 \\
(44-63)\end{array}$ & 64 & 36 & 17 & 19 & $1: 1.1$ \\
\hline
\end{tabular}

Table 2. Oviposition, fecundity and longevity of $E$. osseatella moths fed on $10 \%$ sugar solution at $27 \pm 2{ }^{\circ} \mathrm{C}$ and $65 \pm 5 \%$ R.H.

\begin{tabular}{|c|c|c|c|c|c|c|}
\hline \multicolumn{3}{|c|}{ Ovipositional periods (days) } & \multicolumn{2}{c|}{ N. of eggs/female } & \multicolumn{2}{c|}{ Longevity(days) } \\
\hline Pre-oviposition & Oviposition & Post-oviposition & Daily & Total & Female & Male \\
\hline $1.8 \pm 0.8$ & $3.1 \pm 1.1$ & $1.2 \pm 0.8$ & $46.6 \pm 6.6$ & $147.2 \pm 9.2$ & $6.2 \pm 1.2$ & $4.4 \pm 1.2$ \\
$(1.0-3.0)$ & $(1.5-5.3)$ & $(0.5-3.0)$ & $(2-157)$ & $(24-337)$ & $(3-9)$ & $(3-8)$ \\
\hline
\end{tabular}

On the other hand, Harakly (1965) found that the egg, larval, pupal and adult stages of $E$. osseatella lasted 7, 14-15, 20.6 and 3-4 days, respectively at $28^{\circ} \mathrm{C}$. Rivnay (1966) indicated that the mortality of $E$. osseatella eggs reached 27 and $57 \%$ at 19 and $30^{\circ} \mathrm{C}$, respectively. Adults survived 7-10 days. Ferial (1969) stated that the egg, larval and pupal stages of $E$. osseatella required $3-13$, 24-159 and $9-39$ days, respectively at $26.3^{\circ} \mathrm{C}$. The preoviposition and oviposition periods of the pest averaged 0.6 and 6.0 days, respectively. The male and female lived 1-12 and 2-15 days, respectively
Table 3. Life table parameters of E. osseatella females fed on $10 \%$ sugar solution at $27 \pm 2^{\circ} \mathrm{C}$ and $65 \pm 5 \%$ R.H.

\begin{tabular}{|l|l|}
\hline \multicolumn{1}{|c|}{ Parameter } & Value \\
\hline Mean generation time $(T)$ (days) & 54.22 \\
Net reproductive rate $\left(\mathrm{R}_{\mathrm{o}}\right)$ & 28.09 \\
Intrinsic rate of increase $\left(\mathrm{r}_{\mathrm{m}}\right)$ & 0.062 \\
Finite rate of increase $\left(\exp . \mathrm{r}_{\mathrm{m}} / \lambda\right)$ & 1.063 \\
Generation doubling time $(\mathrm{Dt})($ days $)$ & 14.01 \\
\hline
\end{tabular}




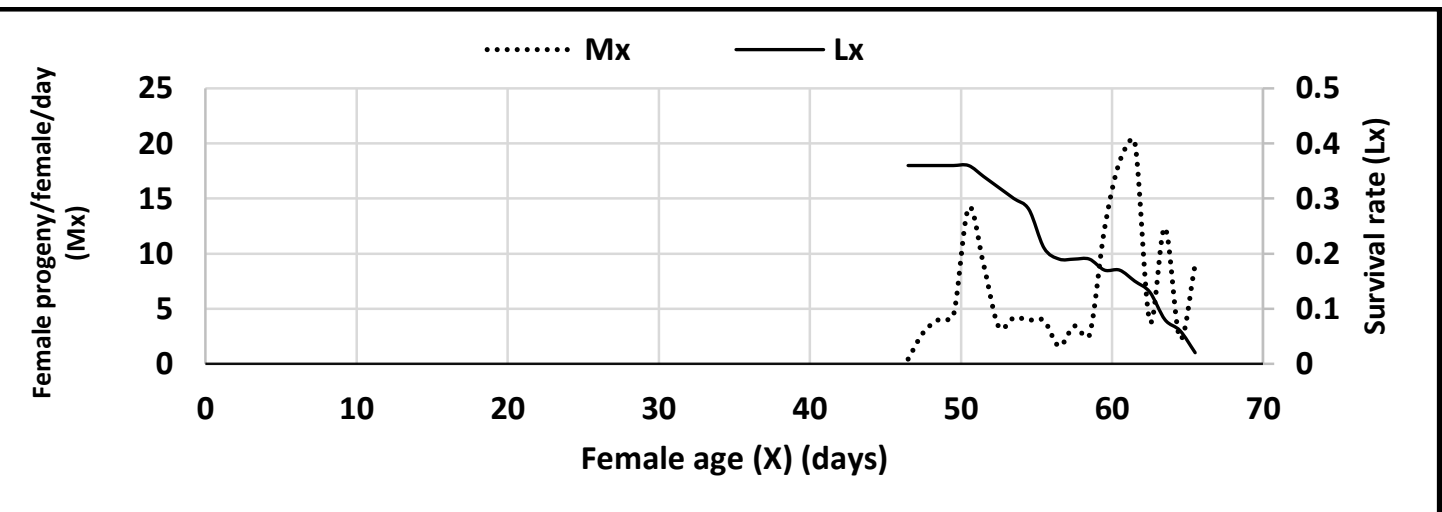

Fig. 1. Age-specific fecundity rate (Mx) and age specific survival rate (Lx) of $E$. osseatella females fed on $10 \%$ sugar solution at $27 \pm 2^{\circ} \mathrm{C}$ and $65 \pm 5 \%$ R.H.

\section{REFERENCES}

Abou-Setta, M.M., Sorrel, R.W. and Childers, C.C. 1986. Life 48: a basic computer program to calculate life table parameters for an insect or mite species. Fla. Entomol., 69, 690-697.

Berlinger, M.J. 1986. The tomato crop. J.G. Atherton and J. Rudich eds. Chapman and Hall, London, pp. 401-440.

Birch, L.C. 1948. The intrinsic rate of increase of insect population. J. Anim. Ecol., 17, 15-26.

Cameron, W.P.L. 1963. Euzophera osseatella in potato tuber. Plant pathol.12 (3), 137.

Ferial, M.L.A. 1969. Studies on the morphology and biology of the egg-plant stem borer, Euzophera osseatella Treit. (Lepidoptera, Pyralidae). M.Sc. Thesis, Fac. of Agric., Alex. Univ., Egypt: 169 p.

Hammad, S.M., Youssef, K.E.H. and Assem, M.A.H. 1968. Biological studies on the eggplant stem borer, Euzophera osseatella Treit. (Lepidoptera: Pyralidae). Bull. Soc. Ent. Egypte 52: 45-47.
Harakly, F.A. 1974. Preliminary survey of pests infesting solanaceous truck crops in Egypt. Bull. Soc. Ent. Egypt, 58, 133-140.

Herakly, F.A. 1965. External morphology and lifehistory of the egg-plant stem borer, Euzophera osseatella Treit. (Lepidoptera: Pyralidae). Bull. Soc. Ent. Egypte 49, 259-276.

Moftah, E.A.M., Aly, F.K., Soliman, A.A. and Abdel-Naby, M.A. 1985. Population dynamics of the potato tuber worm Phthorimae operculella (Zeller), and the egg-plant stem borer Euzophera osseatella (Treitscko) in Middle Egypt. Minia J. Agric. Res. \& Dev. 7 (2), 459-474.

Oda, M.I.M. 2012. Ecological and biological studies on Euzophera osseatella. M. Sc. Thesis, Fac. of Agric., Al-Azhar Univ., Egypt: 130 p.

Rivnay, E. 1966. A contribution to the biology of the eggplant stem borer, Euzophera osseatella Treit. (Lep.: Pyralidae). Israel J. Entomol., 1,114.

Shaheen, A.H. 1979. Survey of pests attacking tomato in Egypt with some ecological notes. Agric. Res. Rev. 55 (1), 49-57. 


\title{
النواحي الحيوية ومعايير جدول حياة حفار ساق الباذنجان (رتبة الحشرات حرشفية الأجنحة: فصيئة بيراليبىى)
}

\author{
سمر مجدى عباس - عبدالمحسن محمد هيكل - لطقى عبدالحميد يوسف

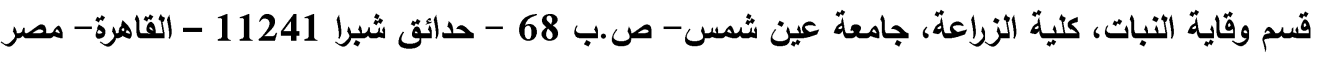 \\ "Corresponding author: samarmagdy1726@gmail.com
}

Received 12 September, 2018, Accepted 9 October, 2018

بلغ متوسِط مدة الجيل لحفار ساق الباذنجان

54.22 يوما. كان معدل التزايد الصافى ومعدل التزايد

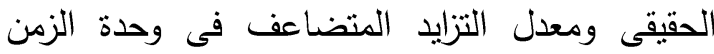

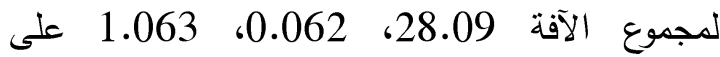

التوالِّى. وصلت مدة تضاعف جيل الافة الحشرة 14.01

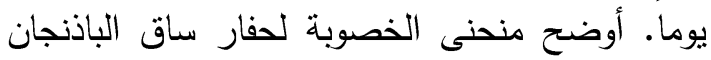

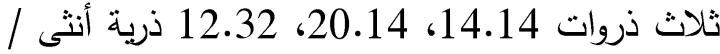

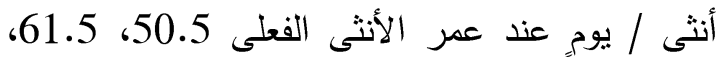

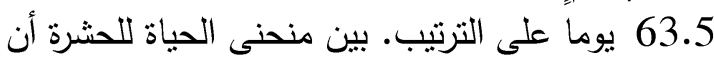

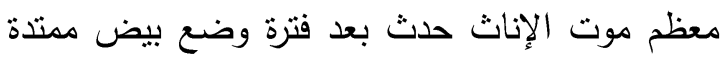
لتعويض فنثل معظم البيض فى الوصن الوصول إلى الأطوار غير البالغة النضج (64\%).

الكلمات الدالة: حفار ساق الباذنجان، النواحى الحيوية، معايير جدول الحياة.

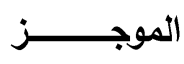

تم دراسة النواحى الحيوية ومعايير جدول حياة حفار ساق الباذنجان (رتبة الحشرات حرشفية الأجنحة:

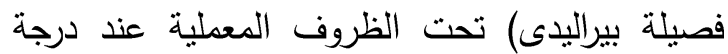

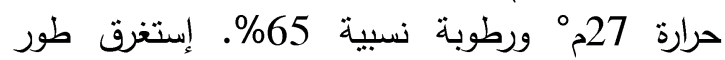
البيضة واليرقة والعذِراء لحفار ساق الباذنجان 5.8،

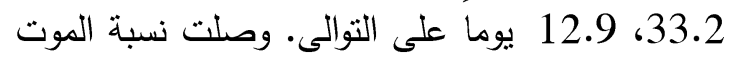
فى الأطوار المقابلة 14، 33، 37، 13 \% ع على الترتيب. كانت النسبة الجنسية فى الحشرة فى صالح الإناث (14، 13 (1)

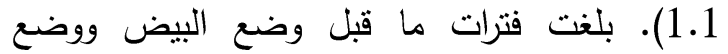
البيض وما بعد وضع البيض فى الآفة 1.8، 1.2 يوماً على التوالى. كانت التئ أعداد البيض اليضة اليومية

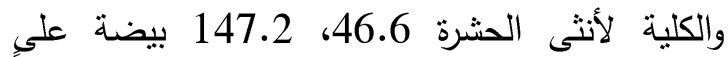
الترتيب. عاش ذكر وأنثى الحشرة 4.4، لأش 6.2 يوما

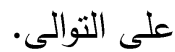

